\title{
Analysis of nutrition (and food) education syllabus of nutrition undergraduate courses
}

\author{
Análise de planos de ensino de educação \\ (alimentar e) nutricional nos
}

cursos de nutrição

\author{
Elisabetta RECINE ${ }^{1}$ \\ Erika Blamires Santos PORTO ${ }^{1}$ \\ Patrícia Martins FERNANDEZ ${ }^{1}$ \\ Maína Ribeiro PEREIRA'
}

\section{A B S T R A C T}

\section{Objective}

To analyze the Nutrition Education discipline syllabus in Nutrition undergraduate courses in Brazil.

\section{Methods}

This is a qualitative, exploratory, descriptive cross-sectional study, carried out in the form of survey. A letter of invitation was sent to higher education institutions that had at least one class that graduated by the end of the first semester of 2010 and provided the Nutrition education discipline syllabus. The software Analyse Lexicale par Contexte d'un Ensemble de Segments de Texte (Image, Toulouse, França) version 4.7 was used in the textual data analysis of the syllabuses, and the social representation theory was adopted as the theoretical model.

\section{Results}

Data were obtained from 46 participant higher education institutions (11.7\%), of which 18 were public institutions. Lexical analysis revealed the formation of two independent axes, which were composed respectively of words from the reference list of relevant books and articles included in the discipline syllabus and words related to the discipline program, indicating a lack of association between "reference list" and "text". As for the syllabus content, it was observed that the educational process should be composed of analysis, planning, and implementation, but these three steps (defined by classes) do not seem to be related or connected to each other, demonstrating a nutrition (and food) education teaching gap.

\footnotetext{
1 Universidade de Brasília, Faculdade de Ciências da Saúde, Departamento de Nutrição. Campus Universitário Darcy Ribeiro, Sala 9C, Asa Norte, 70910-900. Brasília, DF, Brasil. Correspondência para/Correspondence to: E RECINE. E-mail: <recine@unb.br>.
} 


\section{Conclusion}

This analysis revealed the need to restructure the nutrition education syllabuses to promote greater integration between theory and practice. However, in order to ensure higher qualification and competence of future professionals, it is suggested deeper consideration including the political-pedagogical projects of nutrition undergraduate programs and the Diretrizes Curriculares Nacionais (National Curriculum Guidelines).

Keywords: Food and nutrition education. Nutritionists. Professional practice.

\section{RE S U M O}

\section{Objetivo}

Analisar os planos de ensino da disciplina de Educação Nutricional em cursos de Nutrição no Brasil.

\section{Métodos}

Trata-se de um estudo qualitativo, exploratório e descritivo, de caráter transversal, tipo survey, realizado por meio de carta-convite às instituições que possuíam turmas formadas até o término do primeiro semestre de 2010 e que disponibilizaram planos de ensino da disciplina de Educação Nutricional. Para a realização da análise textual dos planos de ensino, foi utilizado o software Análise de Dados Textuais (Image, Toulouse, França) versão 4.7 e foi adotada a teoria das representações sociais como modelo teórico.

\section{Resultados}

Os dados da pesquisa foram oriundos de 46 instituições $(11,7 \%)$, das quais 18 eram públicas. A análise lexical revelou a formação de dois eixos independentes, compostos, respectivamente, por palavras originárias das bibliografias apresentadas nas ementas da disciplina e por palavras relacionadas ao programa da mesma, representando uma falta de associação entre 'referências' e 'texto'. Quanto ao conteúdo programático, observou-se que o processo educacional deve ser composto por análise, planejamento e implementação, mas essas três etapas (definidas por classes) não parecem estar articuladas, revelando uma fragmentação no ensino da educação (alimentar e) nutricional.

\section{Conclusão}

Esta análise revelou a necessidade de reestruturação das ementas da disciplina Educação Nutricional no sentido de promover uma maior integração do binômio teoria-prática. Contudo, para uma maior efetividade de atuação dos futuros profissionais, sugere-se um repensar mais amplo, que envolva os planos políticos pedagógicos dos cursos e as Diretrizes Curriculares Nacionais.

Palavras-chave: Educação alimentar e nutricional. Nutricionistas. Prática profissional.

\section{INTRODUCTION}

In the first Nutrition undergraduate courses in Brazil, during the 1930s and 1940s, nutrition education as an academic discipline was linked to the pedagogy field. According to Boog ${ }^{1}$, the first national minimum curriculum established by the Ministério da Educação e Cultura (MEC, Ministry of Education and Culture) included the discipline "Pedagogy Applied to Nutrition" in 1964. Two years later, the $1^{\text {st }}$ "Nutritionists Training Conference - Dietitians of Public Health (Cepandal)" was held in Venezuela, in which it was recommended the grouping of fields in the curriculum and the need for training of
Nutritionists with a social vision, through the pedagogic science field, which would have 1/5 of the course load. During the $2^{\text {nd }}$ Cepandal, held in São Paulo in 1973, the academic discipline "Pedagogy Applied to Nutrition" was inserted into the Applied Nutrition field, together with the disciplines "Nutrition Assessment" and 'Public Health Nutrition'. Despite the presence of the pedagogical dimension in the formal education of nutritionists, the emphasis remained on the biological and hospital-centric approach, focusing on the individual and the specialized education based on fragmented disciplines of the basic and professional training cycles². 
The supremacy of the biomedical model in the formal education and professional training of nutritionists was justified by the need for a nutritional intervention due to the high rates of undernutrition and nutritional deficiencies the country had been facing since the early $1940 \mathrm{~s}^{3}$. An example is the creation of the Comissão Nacional da Alimentação (CNA, National Food Commission), in 1945. One of the priorities of this commission was to provide nutrition education aiming at overcoming nutritional deficiencies. After it was dissolved, the Instituto Nacional de Alimentação e Nutrição (INAN, National Institute of Food and Nutrition) was established in 1972, and controlling those deficiencies remained a priority with the development of nutritional supplementation programs for at-risk groups, such as pregnant women, children, and nursing mothers, who were also the target of educational campaigns at that time. Despite all INAN efforts to implement programs that could mitigate the social, economic, political, and regional determinants of nutritional problems in the country ${ }^{4,5}$, the nutrition education approach was aimed only at campaigns for the provision of new foods to vulnerable populations. Discussing the process of developing Food Education programs, especially in the first decades of the last century, Lima ${ }^{6}$ argued that the central issue was not simply understanding the social differences in geographical contexts or identifying vulnerable populations for the development of specific actions. The author believed that the aim was to understand how the socio-cultural aspect of nutrition is embedded in relationships that permeate the different social classes, considering the historical moment in which these differences are perceived. Thus, the food and nutrition issues and their relationship with the Education field can be viewed differently. This "gap" between nutritional status and socioeconomic classes contributed to impact the effective implementation of Nutrition Education programs from the end of the 1970s to the early 1990s'.
However, in the late 1990s, nutritional education was the issue that led to the development of an action plan to deal with the double burden of diseases, in the context of the Sistema Único de Saúde (SUS, Unified Health System), and was meant to be an intervention axis in the $4^{\text {th }}$ guideline of the $1^{\text {st }}$ edition of the Política Nacional de Alimentação e Nutrição (PNAN, National Food and Nutrition Policy), in 19997. Some years later, in 2003, the program Fome Zero (Zero Hunger) contributed to the promotion of practices for healthy eating established by the PNAN, leading to increased visibility and importance of this issue in public policies.

As a result of the sanitary reform, popular health education emerged in the formal education of nutritionists and health professionals in general. It consisted of a proposal concerning the planning, implementation, and participatory community assessment of educational actions on social determinants of health. It also included a number of initiatives aimed at establishing links between universities, health services, and the community. Concomitantly, public hearings that enabled the discussion of the Diretrizes Curriculares Nacionais (DCN, National Curriculum Guidelines) and their regional peculiarities were held in the $1990 \mathrm{~s}^{2}$. These guidelines were issued in 2001 establishing that teaching should promote critical thinking, reflection, and the development of activities that combine theory and practice to be incorporated into pedagogical strategies in teaching, research, and academic extension programs ${ }^{8,9}$.

In the years following the publication of the $1^{\text {st }}$ edition of the PNAN and the DCN, the launch of the Zero Hunger Program in 2003, reopened the debate, bringing government and civil society together, over the need for a national policy on Segurança Alimentar e Nutricional (SAN, Food and Nutrition Security), introduced in 2010. These factors led to the broadening of the Nutrition Education concept, which has since then encompassed the term "food". Therefore, Educação Alimentar e Nutricional (EAN, Food and 
Nutrition Education) is a strategy that can contribute to ensure the SAN and the recognition and respect of the Direito Humano à Alimentação Adequada (DHAA, Human Right to Adequate Food), and it is considered an intersectoral and transdisciplinary action ${ }^{10}$. Since then, this strategy has encompassed all stages of the food system, from aspects related to food and feeding, production, supply, and processing to the nutritional aspects. In that same year, the Ministry of Health organized the 'State and National Seminars on Food and Nutrition' integrated with the SUS - PNAN 10 years, in order to revise and update the PNAN, adapting it to the new epidemiological reality of the country and the challenges of providing nutritional care in the SUS. One result of this process was the adoption of EAN as the crosscutting theme in the 9 guidelines of the new edition of the PNAN, published in $2011^{11}$. Another important element was the publication of Marco de Referência de Educação Alimentar e Nutricional (Reference Framework for Food and Nutrition Education) for public policies, which, in the context of the recognition and respect of the Human Right to Adequate Food and ensuring Food and Nutrition Security, classified the EAN as a field of knowledge and continuous, permanent, transdisciplinary, intersectoral, and multidisciplinary practice aiming to promote the autonomous and voluntary healthy eating habits. In order to do so, it is necessary to use active and problem-posing educational approaches and resources that can promote the dialogue between individuals and population groups considering all stages of life course and food system and the interactions and significance that determine the eating habits ${ }^{12}$.

Alongside with this political and institutional process of EAN as an area of public action and professional training, the complexity of the determinants of eating patterns promotes an interaction between the actions for promoting healthy eating and intervention actions in the individual, social, and environmental spheres. This aspect poses particular challenges to the role and impact of EAN. As a result of common sense, the so-called food (re-) education has taken on an increasing importance, indicating, on the other hand, the need to improve the training and the actions of nutritionists in this field, for which two objectives have to be achieved. The first refers to the expansion of the competencies and professional training of nutritionists from the biology/technical training, which makes the nutritionist a "mere diet prescriber" to an active and critical professional of the hegemonic food system. The second is related to combining the dialectical pair theory and practice, starting at the academic professional training, as a fundamental guidance and experience to deal with the many determinants food and nutrition security in the country ${ }^{13,14}$. Therefore, the fields of nutrition and health, within the context of human rights, require the nutritionist to make use of problem-posing strategies focusing not only on the epidemiological profile of the population, but also in the social, cultural, economic, and political determinants for the planning of a nutritional care in general and for food and nutrition education in particular. Accordingly, this article aims to analyze the Nutrition Education discipline syllabus in nutrition undergraduate programs in Brazil.

\section{METHODS}

This is a qualitative, exploratory, descriptive cross-sectional study, carried out in the form of survey. The documental basis was based on the primary data of the "Estudo de avaliação da formação do profissional nutricionista e seu alinhamento com as políticas de saúde no Brasil" (An analysis of the formal education and professional training of the nutritionist and its alignment with health policies in Brazil), a study financially supported by the Brazilian Ministry of Health.

In order to identify potential participants, an invitation was sent to all higher education institutions (public and private) in the country that had nutrition undergraduate programs. A search 
was conducted in the database of the Nutrition school contacts, created by the Conselho Federal de Nutricionistas (CFN, Federal Council of Nutritionists), and the contact details of potential participants were updated by initial contacts via phone calls and e-mails. The inclusion criteria for participation in this study were higher education institutions which had at least one class that graduated by the end of the first semester of 2010 and which would provide the Nutrition Education discipline syllabus for that same year. Initially, 392 colleges/universities with Nutrition undergraduate programs were identified, of which 55 were public institutions (14\%).

The invitations to participate in the study, containing a cover letter and the Informed Consent form, were sent via e-mail to the course coordinator. The invitations were also extensively posted on the websites of partner institutions, such as Conselho Federal de Nutricionistas, Conselho Nacional de Segurança Alimentar e Nutricional, and Coordenação Geral de Alimentação e Nutrição do Ministério da Saúde. Data were gathered between September 2009 and February 2010. The present study was approved by the Research Ethics Committee of the Universidade de Brasilia (UnB, University of Brasilia), protocol $n^{\circ}$ 97/2009.

The sample was composed of 296 courses (75.5\%) that had at least one class that graduated by the end of the first semester of 2010, of which 46 were public higher education institutions. After being requested to provide their Nutrition Education discipline syllabus, 46 institutions $(11.7 \%)$ responded, of which 18 were public institutions.

The software Analyse Lexicale par Contexte d'un Ensemble de Segment de Texte (ALCESTE, Image, Toulouse, France) version 4 was used in the textual data analysis of the syllabuses ${ }^{15}$. It conducts a first analysis of the vocabulary of a corpus and makes the dictionary of these words with their roots and frequencies, distinguishing word classes that represent differing forms of discourse concerning the topic of interest ${ }^{16,17}$. The present study was based on the "epistemological relations" between this technique and the social representation theory ${ }^{18}$. According to Moscovici ${ }^{19}$, social representations are explanatory hypotheses about socially relevant objects/institutions, formulated based on the connection of meaning identified in the text.

The software carries out a lexical analysis of the words in the texts in four steps ${ }^{15-17,20}$, as follows:

(a) Reading of documents and making up of a dictionary of words in their reduced (root-) form. The corpus to be analyzed (the text) was divided into specific topics ensuring homogeneity, relevance, and syncronism ${ }^{17}$. Accordingly, the Nutrition Education discipline syllabus was defined as the Initial Context Unit.

(b) Definition and selection of the Elementary Context Unit (ECU) and Hierarchical Descending Classification (HDC). The segmentation of the text into smaller fragments generated for analysis, called Elementary Context Units (ECU), was automatically defined by the program, and it is based on word length (with an approximate sequential break after three lines or eight to ten words and/or a segment of the text). The ECU classification results from the grouping of segments with word co-occurrences. Subsequently, the ECU was divided according to the frequency of the reduced forms identified, and matrices were generated with the purpose of separating the different ECU. Based on these matrices, the Hierarchical Descending Classification method was applied, which presents the text organized into different classes that address the same topic or subject addressed within that same text ${ }^{16-18}$. Therefore, for each class, the program computes for each class a list of words that are characteristic for that class using the chi-square test $\left(\chi^{2}\right)$; the strength of association between each word and its class is expressed by a $\chi^{2}$ value. Thus, the larger this value, the more important the word is for the statistical construction of the class $^{16}$. The reading of the most significant reduced words, the missing words, and the most characteristic ECU 
of each class or the lists created - all classified by decreasing $\chi^{2}$ - allowed the semantic interpretation of the data by the researchers, considering their knowledge of the conceptual field analyzed ${ }^{15-16,18}$.

(c) Description of the classes. In this step, based on the calculations made in the previous step, which enabled the description of each class, a Correspondence Factor Analysis (CFA) was carried out. Spatial representations were created and presented in a factorial plane. This spatial representation of variables, composed of axes, one horizontal and one vertical axis ( $X$ and $Y$ axes), allowed the analysis of the associations between the classes and of the potential dissimilarities and complementarities between them ${ }^{15-18}$.

(d) Additional calculations. The most characteristic ECU and the most frequently repeated sentence segments in each class were generated. The hierarchical ascending classification, formed by the intersection between the ECU classes and significant reduced forms (which are therefore characteristic for the same class), allowed the visualization of the internal organization and the association between the most significant words in each class. Thus, the hierarchical ascending classification contributed to the understanding of the contexts of these words and to the analysis of the interrelationship between them ${ }^{15-18}$.

The analysis carried out highlights the clusters (lexical classes) of words with the same meaning. In the first stage of the analysis (Hierarchical Descending Classification - HDC), the ALCESTE identifies the common field, i.e., wherever there is a high recurrence rate of significant $\chi^{2}$ values, there is a potentially valid core meaning (Figure 1). In the second stage of the analysis (factor analysis), the program identifies the positioning of the classes on the two axes, (vertical and horizontal), which are presented in a factorial plane of four equal quadrants, in which it is possible to analyze the presence of potential dissimilarities and complementarities between the lexical classes (Figure 2).

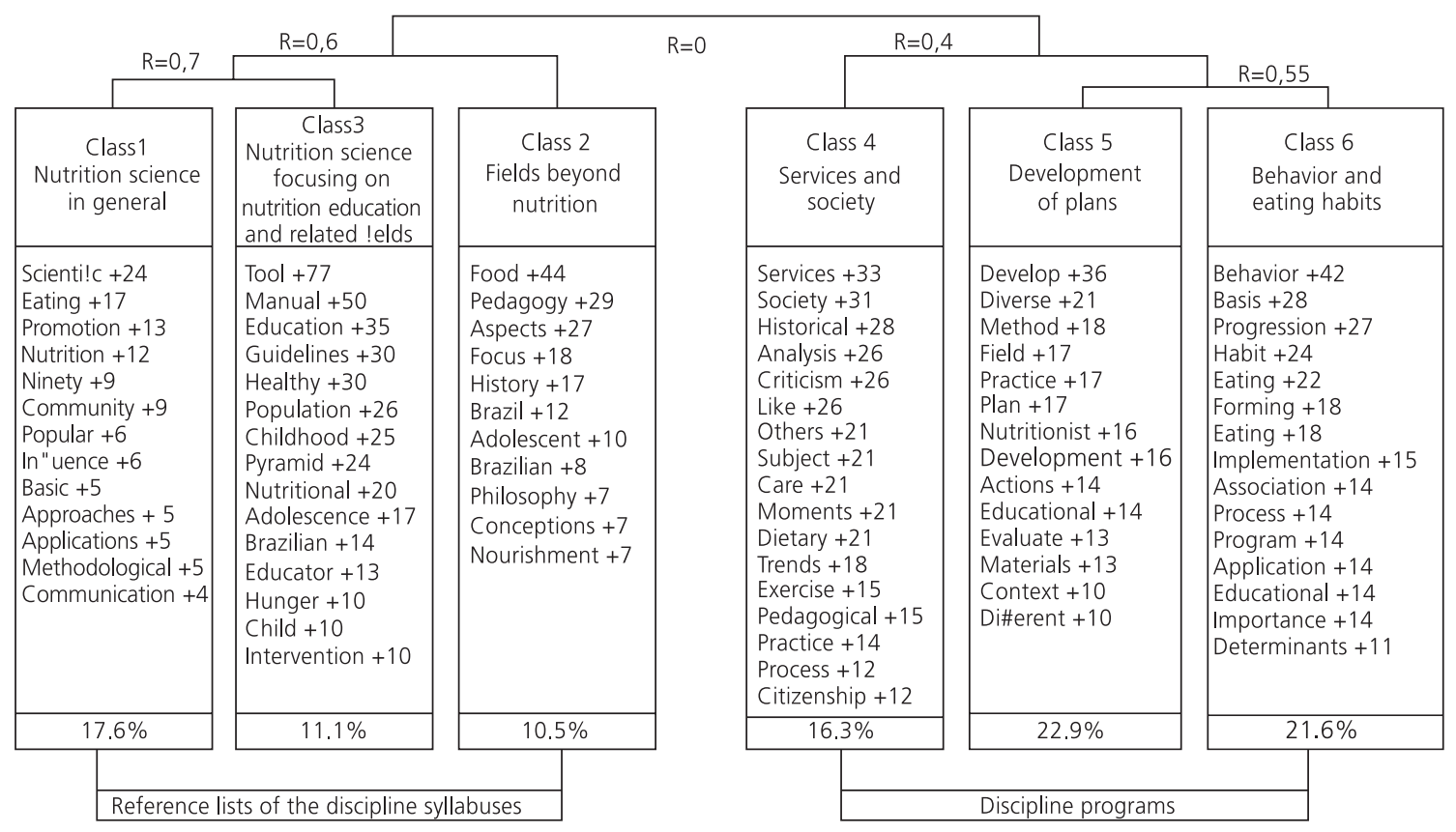

Figure 1. Hierarchical descending classification of the corpus of the analysis of the Nutrition Education discipline syllabuses. Brazil 2010. 


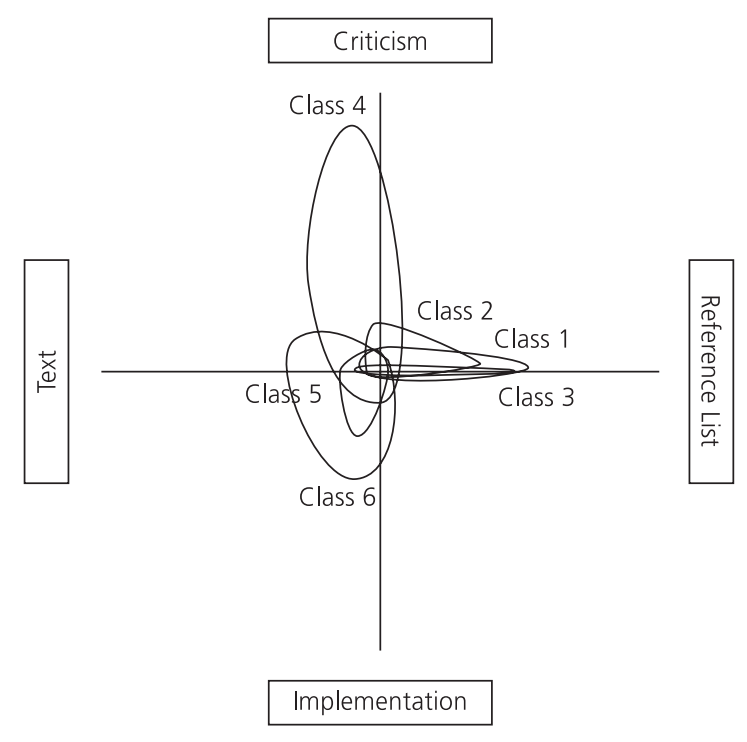

Figure 2. Factor analysis of correlations between the Nutrition Education discipline classes. Brazil, 2010.

\section{RE S U L T S}

Of the 46 syllabuses analyzed, 18(39.0\%) were from public higher education schools and $28(61.0 \%)$ were from private institutions; two $(4.3 \%)$ were from the Northern region, three $(6.5 \%)$ from the Northeastern region, eight (17.4\%) from the Midwest region, twenty-one $(45.7 \%)$ from the Southeastern region, and twelve (26.1\%) from the Southern region. Among the total of 392 existing institutions in 2010 with nutrition undergraduate programs, proportionally more public universities participated in the study, i.e., $32.7 \%$ (18 of 55 ) were public and $8.3 \%$ (28 of 337) were private universities.

With regard to the analysis of the Nutrition Education syllabuses, the words with the largest $\chi^{2}$ values are more associated with the term education than with "nutrition, and the term communication remained important". Therefore, two major sets of words were formed: the first set of words included, for example, "Communication as a Technique Used as a Means for Forming Eating Habits"; "development and implementation of the Educational Plans and
Programs and the Teaching-Learning Process"; and "the Methodologies Used by the Educator Appear as the Basis for Changes in Eating Behavior". In the second set of words, the following stand out: "professional practice as educational practice based on different resources and pedagogical strategies"; "the Role of the Educator/Education is to Develop Such Strategies, from the purposes and history of nutrition education to its criticism"; and finally "didactic materials and some teaching tools related to popular pedagogy and community for nutrition education".

The hierarchical descending classification data, illustrated in Figure 1, show two independent axes $(R=0)$, each one formed by three classes; axis 1 (classes 1, 2, and 3) was composed of text units from the reference list of relevant books and articles included in the discipline syllabus, and axis 2 (Classes 4, 5, and 6) was composed of units related to the discipline program.

Each one of the first three classes referred to a specific type of literature, as defined below. Nutrition science in general (class 1), which maintains a relationship with class $3(R=0.7)$ since it is also addresses nutrition topics although focusing on nutrition education and related processes. This last class involves issues related to how nutrition education should be provided, and it also includes some tools such as the food "pyramid and healthy eating guidelines and manuals for the Brazilian population". In Class 2, which was a little less associated with to class 1 and 3 (as mentioned above) ( $R=0.6)$, there was prevalence of the term food, which was much more frequent than the term "eating, incorporating pedagogy, history, philosophy" aspects, and concepts and many nutrition approaches. The elements that associate nutrition and other disciplines in the contents of Nutrition Education syllabuses are present in class 2 .

On axis 2, Nutrition Education in class 4 appears associated with services and society, emphasizing the terms analysis, historic, and criticism. Care and dietary seem to set the tone 
of nutrition education. Practice, process, exercise, pedagogical, and educational aspects are other words with large $\chi^{2}$ values. "Concept, role, education limits, and limits of educational aspects in general are mentioned". In summary, it was observed that health services are the "locus" of the nutritional education analysis, in a critical way in relation to its role in society, according to the historical moment and revealing trends in professional practice. Terms such as "eating, nourishment, feed, habits, and behaviors" were not present in class 4 .

The words that were present only in class 5 are develop, diverse, and plans. The first two had the highest $\chi^{2}$ values, followed by "method", area, "practice", plan (verb), "nutritionist", actions, and "evaluate". Therefore, the critical basis of education, nutrition education, and widespread nutritionist practice were related to class 4 , and class 5 was more related to education practice and implementation, i.e., to how education should be planned and provided. The competences required to deal with a plurality of fields within the parameters in class 4 are given in class 5, thus establishing the relationship between the classes, as shown in Figure $1(R=0.4)$.

In the sixth and last class, it was observed the same behavior seen in classes 4 and 5 $(R=0.55)$, changing from generic into specific, i.e., it changes from the basis into the application or practice of knowledge. The most important words were "behavior, development, habit, feed, forming, and eating", and the words progression and determinants were exclusive to this class. The terms that were characteristically absent in class 4 appeared in class 5 as significant words, indicating a stronger association with nutrition in general. Behavior, as a central notion, was associated with habit formation, its "determinants and basis" that are related to the notion of eating habits. Understanding the formation of this habit (behavior) is essential for the "planning, implementation, and development of the educational program".

\section{Factor analysis of the Nutrition Education discipline classes}

Factor analysis summarizes the behavior of the variables studied (Figure 2). The proximity of the words on the factor plane shows a high correlation between them since even if two topics are treated differently, as they are in fact two independent subjects in terms of content, they may appear somewhat associated with one another.

It can be seen that on the horizontal axis (Figure 2) the Classes 1, 2, and 3 are more associated than differentiated; there is almost an overlapping of classes. On the other hand, there is a disaggregation on the vertical axis, indicating a certain distance between class 4 and classes 5 and 6 . Since the first three classes refer to the reference lists and the other three classes $(4,5$, and 6) contribute to an opposite polarization of this axis, there is a lack of association between "text" (discipline programs) and "reference list" (the list of literature that supports those programs).

On the vertical axis, the lexical content changes from a critical approach in the discipline (emphasized by Class 4) into objects and strategies of the discipline, without relating one to another. In Class 6, it can be clearly seen that nutrition education aims at changing eating habits through the use of different methodological steps, but in its lexical universe there are no terms that focus on the critical thinking addressed by Class 4 or terms that could also be related to eating habits or behaviors and to the planning and implementation of educational actions, etc. Terms such as "historical, process, citizenship, and subject" are those that were less associated with classes 5 and 6 . In other words, the discipline addresses that the educational process should be composed of analysis, planning, and implementation, but these three steps (defined here by the classes) do not seem to be related to each other, indicating a nutrition (and food) education teaching gap. 


\section{DISCUSSION}

It is worth highlighting the importance of the present study in a scenario of very few publications addressing this topic, including international publications, even if it does not reflect the Brazilian reality in its totality in terms of teaching nutrition education due to the number of syllabuses that could be evaluated. This study is therefore a starting point.

The analysis of the nutrition education syllabuses raised several issues in terms of the training and education of future professionals. The main results of this study will be discussed separately. Initially, the approaches to teaching nutrition education and the discipline pedagogical strategies will be discussed, followed by the discipline contents and their interrelations.

\section{Approaches to teaching nutrition education and pedagogical strategies of the discipline}

Based on the lexical analysis of the words with the largest $\chi^{2}$ values in the syllabus, it can be said that there are various aspects of Cartesian logic in the formal education of nutritionists, prioritizing the traditional teaching approach, such as in the association between the word "education" and "communication as a technique used as a means for forming eating habits"focusing on the dietary treatment (first set of words) - and in the association of the words "analysis", historical, and "criticism" with education aiming at "care and "dietary" (Class 3 of $\mathrm{HDC}$ ).

These associations suggest that a priority in terms of knowledge/information has been given to dietary education, which, according to Vincha et al. ${ }^{21}$, is based on the context that "there is someone who knows and teaches someone who does not know". This indicates a majoritarian thinking of information sufficiency, i.e. the knowledge about the risks would be enough for people to adopt healthy eating habits ${ }^{21-22}$.
There is considerable evidence that the educational practices based on the "contentist, normative, and scientificist" perspective of information transfer do not result necessarily in changes in behavior. Given the evidence of the ineffectiveness of this approach, the gap between discourse and pedagogical practice in health can be identified. The expectation for new and effective practices and better results is currently based on the representations of the subject and its role in the (re) development of new practices ${ }^{22}$.

Contributing to the reflection upon the challenges of "teaching and learning how to do", Recine et al. ${ }^{14}$ argued that the supremacy of the traditional knowledge of public health, such as epidemiology and contents of the mother-child area, can still be identified in the Public Health disciplines of the Nutrition programs of colleges or universities. Even within this field of knowledge and action, the present study found a weak association between knowledge and disciplines, theory, and practice. This may reflect a tendency to associate the "Learning How to Do" only to the training of people to perform tasks in the context of dietary care, which could also result in many challenges to improve the teaching model present in the Brazilian educational culture and encompass the current aspects of the EAN discipline due to the extensive social, political, economic, and health changes that the country has undergone in recent decades.

This traditional teaching model is probably reflected in the next result to be discussed. In the second set of words in the syllabuses of the Nutrition Education discipline, is the "professional practice as an educational practice based on different resources and pedagogical strategies". However, it was not possible to identify these strategies and the desired professional practice.

Discussing the Food and Nutrition Education advancements due to the Reference Framework for Food and Nutrition Education for public policies ${ }^{12}$, Amparo-Santos ${ }^{23}$ highlighted the need to develop new teaching methods for this discipline. Accordingly, the Consenso de habi- 
lidades e competências do nutricionista em saúde coletiva has proposed the development of competencies for Food and Nutrition Education skills aiming at the observation of realities considering the socioeconomic and cultural factors that influence the use of health services for nutritional care, focusing on the recognition and promotion of the community as "subjects" to improve their eating habits, health, and nutrition ${ }^{24}$. As for the promotion of health, the EAN focuses on the acknowledgement of behavioral aspects and cultural eating patterns, especially on the sustainable resources and actions according to the sociocultural context of population groups and communities ${ }^{14}$.

Pinheiro et al. ${ }^{25}$ conducted interviews with professors, undergraduate students, and students who had graduated from Nutrition programs about the formal education and professional training of nutritionists in public health and found that in terms of skills and competencies the student is expected to acquire, there is still a need for teaching approaches that are able to integrate active methodologies applied to reality. These authors also found that these are fundamental issues to change the structure of the current syllabuses. According to Amparo-Santos ${ }^{23}$, the training and education of students is directly related to the training and education that their teachers had, i.e. the teaching plans are developed based on the teachers' own experiences. Considering that undergraduate studies last for a few years only, but professional practice may last for decades and that skills and competencies change quickly, the use of a methodology aimed at liberating education to formally train active professionals who are able to 'learn how to learn' is therefore essential26.

In Brazil, Paulo Freire's theory of education has greatly contributed to the development of the teaching-learning process between teacher-student, which should be based on the movement that goes from action to reflection and from reflection upon action to a new action (action-reflection-action), without distinguishing the movements of who the student and the teacher are, but rather providing a problem-posing method of education. Accordingly, other undergraduate health programs have been using active problem-posing methodologies and have achieved promising results, such as the required experience for students to pave their own way believing in their potential, with higher self-esteem, autonomy, motivation, and a closer interaction between school and care service reaching a proper understanding of the diversity of needs that healthcare professionals face in their daily practice ${ }^{27-29}$. Among others, these programs have started a way to improve the traditional model of education aiming at a teaching and learning process that considers the underlying complex reality.

Therefore, given the lack of definition about the pedagogical strategies to adopt and the professional practice to achieve, the Consensus on skills and competencies of nutritionists in public health ${ }^{24}$ has established that reformulating the teaching and learning process is the only way to enable new pedagogical projects, new levels, and new insights into training professionals able to work on interdisciplinary and multidisciplinary teams to meet current demand.

Initiating the discussion about the syllabuses' contents, it is worth mentioning the presence of the class of words (Class 6 of HDC) that addresses eating behavior and its determinants since understanding the formulation of this habit is essential for the planning, implementation, and progression of the educational program. The presence of this class indicates an improvement in terms of a change in the Brazilian formal undergraduate education over the decades, which can affect, even slightly, the professional practice, as reported by Vincha et al. ${ }^{21}$, in a study comparing Nutrition Education groups in terms of primary health care in two different contexts, São Paulo and Bogotá. After a thorough evaluation, the authors concluded that the perceptions and practice of the professionals 
from both cities were in transition from the traditional to a more humanistic healthcare approach. However, the authors highlighted the urgent need for the qualification of human resources to meet current demands in healthcare and health policies.

Therefore, in order to maintain such progression, this new class of words has to be connected with the other classes of this discipline and this and the other classes should have an effective theoretical framework to ensure educational integrity, which has not yet been identified. The analysis of the relationship between the syllabus classes indicated two important aspects: a weak association between the theoretical framework proposed in the reference lists and the major contents addressed in the classrooms and the lack of association between the contents taught in the discipline.

With regard to the low availability of research relevant to the syllabus contents, in a study $^{9}$ in which 11 Nutrition Education professors of 10 higher education institutions in the State of São Paulo were interviewed, it was found that all of them stated that there was little theoretical basis for the planning of practical activities of this discipline although most of them believe these activities are in fact essential.

An issue arising from this discipline teaching gap, indicated by the positioning and weak relationship between class 4 and classes 5 and 6 , is concerned to how to teach the analysis of nutritional education in a critical way (class 4) if it is unrelated to the eating behavior study (class 6) and weakly related to the development of the educational plans proposed (class 5). Perhaps, one explanation refers to the challenge of promoting the development of skills and competencies that the students need for an effective professional practice, which is a critical education gap. Knowledge construction through critical analysis of available information and experiences can contribute to a transformative professional development towards health promotion and life quality improvement ${ }^{30}$.
Evaluating the political-pedagogical projects of nutrition undergraduate programs, Recine et al. ${ }^{13}$ found a weak relationship between three major aspects in the formal education of nutritionists: expected competencies, actions towards nutritional care, and the program operationalization. Ferreira \& Magalhães ${ }^{31}$ investigated Nutrition curricula and found that the little emphasis is put on political, socioeconomic, and cultural issues concerning health care measures. These authors highlighted the challenges that nutritionists face in conducting an in-depth analysis of the dynamics of eatingrelated problems for an effective professional advising aiming at the promotion of healthy eating combined with the prevention and treatment of diseases, according to the realities of the different population groups.

This situation reflects the challenge of adopting the concept and principles of the Reference Framework for Food and Nutrition Education for public policies ${ }^{12}$. In order to achieve the required results, the EAN has to be combined with structural actions and prioritize self-care and autonomy practices, a topic that was not present in the discipline syllabuses' contents and reference lists. On the other hand, aspects related to food as an intangible heritage and the dialogue between different types of knowledge are also among the major issues raised and challenges posed to the Brazilian society ${ }^{26}$ and universities by this document.

Therefore, it is worth highlighting that those responsible for developing and revising academic programs should take into consideration the relative importance of popular and scientific knowledge and their potential to enable professional practice in different health, social, political, and cultural realities and value the regional diversity of the country ${ }^{14}$.

\section{CONCLUSION}

Considering the epidemiological reality and nutritional status in Brazil, in which there is 
coexistence of undernutrition (with decreasing prevalence and present in specific population groups), overweight, and their comorbidities as different sides of the same problem, the formal education of nutritionists has become increasingly complex concerning the reality and its many determining factors.

Thus, evaluating the EAN in the nutrition curriculum of undergraduate programs in Brazil and determining whether the formal education of nutritionists adheres to the principles and guidelines of the Reference Framework for Food and Nutrition Education for public policies, the "National Curriculum Guidelines", and the Consensus on skills and competencies of nutritionists in public health is of great importance.

As a result, it is concluded that the findings of the present study well demonstrated the need to restructure the teaching-learning plans of Nutrition (and Food) Education in order to promote greater integration between theory and practice and to deepen the theoretical and conceptual basis in the context of the multidimensionality of eating habits. Furthermore, aiming at ensuring higher qualification and competence of future professionals, it is also suggested deeper consideration in order to promote greater integration of this discipline with others in the program since it can be considered an instrumental discipline and that the skills and competencies it provides can and should be applied to all professional practice fields.

\section{CONTRIBUTIONS}

E RECINE contributed to the conception and design of this study, interpretation of results, manuscript writing, and final revision. EBS PORTO, PM FERNANDEZ, and MR PEREIRA contributed to the literature review, interpretation of results, manuscript writing, and final revision.

\section{REFERE N CES}

1. Boog MCF. Educação Nutricional como disciplina acadêmica. In: Garcia RWD, Mancuso AMC. Mu- danças Alimentares e Educação Nutricional. Rio de Janeiro: Guanabara Koogan; 2012.

2. Soares NT, Aguiar AC. Diretrizes curriculares nacionais para os cursos de nutrição: avanços, lacunas, ambiguidades e perspectivas. Rev Nutr. 2010; 23(5):895-905. http://dx.doi.org/10.1590/\$1415-5 2732010000500019

3. Santos LAS. Educação alimentar e nutricional no contexto da promoção de práticas alimentares saudáveis. Rev Nutr. 2005; 18(5):681-92. http://dx. doi.org/10.1590/S1415-52732005000500011

4. Schmitz BAS, Von der Heyde MED, Cintra IP, Franceschini SCC, Taddei JAAC, Sigulem DM. Políticas e programas governamentais de alimentação e nutrição no Brasil e sua involução. Cad Nutr. 1997; 13:39-54.

5. Vasconcelos FAG, Batista Filho MB. História do campo da alimentação e nutrição em saúde coletiva no Brasil. Ciênc Saúde Coletiva. 2011; 16(1):81-90. http:// dx.doi.org/10.1590/S1413-81232011000100012

6. Lima, ES. Gênese e constituição da educação alimentar: a instauração da norma. Hist Cien Saude-Manguinhos. 1998; 5(1):57-84. http://dx.doi.org/ 10.1590/S0104-59701998000100003

7. Brasil. Ministério da Saúde. Secretaria de Atenção à Saúde. Política Nacional de Alimentação e Nutrição. Série B. Textos Básicos de Saúde Brasília: Ministério da Saúde; 1998.

8. Brasil. Conselho Nacional de Educação. Câmara de Educação Superior. Resolução CNE/CES 5/2001. Institui diretrizes curriculares nacionais do curso de nutrição. Diário Oficial da União. Brasília 2001; 9 nov, p.39, seção 1.

9. Franco AC, Boog MCF. Relação teoria-prática no ensino de educação nutricional. Rev Nutr. 2007; 20(6):643-55 http://dx.doi.org/10.1590/S1415-52 732007000600007

10. Brasil. Decreto $n^{\circ} 7.272$, de 25 de agosto de 2010 . Regulamenta a Lei no 11.346, de 15 de setembro de 2006, que cria o Sistema Nacional de Segurança Alimentar e Nutricional - SISAN, com vistas a assegurar o direito humano à alimentação adequada, institui a Política Nacional de Segurança Alimentar e Nutricional - PNSAN, estabelece os parâmetros para a elaboração do Plano Nacional de Segurança Alimentar e Nutricional e dá outras providências. 2010. Diário Oficial da União. 2010; 26 ago, p.6, seção 1.

11. Brasil. Ministério da Saúde. Política Nacional de Alimentação e Nutrição. Série B. Textos Básicos de Saúde 2a ed. Brasília: Ministério da Saúde; 2012.

12. Brasil. Ministério do Desenvolvimento Social e Combate à Fome. Marco de referência de educação alimentar e nutricional para as políticas públicas. 
Brasília: MDS; 2012 [acesso 2016 fev 2]. Disponível em: http://www.ideiasnamesa.unb.br/files/marco_ EAN_visualizacao.pdf

13. Recine E, Sugai A, Monteiro RA, Rizzolo A, Fagundes A. Saúde coletiva nos cursos de Nutrição: análise de projetos político-pedagógicos e planos de ensino. Rev Nutr. 2014; 27(6):747-60. http://dx.doi. org/10.1590/1415-52732014000600009

14. Recine $E$, Gomes RCF, Fagundes AA, Pinheiro ARO, Teixeira BA, Sousa JS, et al. A formação em saúde pública nos cursos de graduação de nutrição no Brasil. Rev Nutr. 2012; 25(1):21-33. http://dx.doi. org/10.1590/S1415-52732012000100003

15. Camargo V. ALCESTE: um programa informático de análise quantitativa de dados textuais. In: Moreira $A$, organizador. Perspectivas teórico-metodo-lógicas em representações sociais. João Pessoa: UFPB; 2005. p.511-39.

16. Kronberger N, Wagner W. Palavras-chave em contexto: analise estatística de textos. In: Bauer MW, Gaskell G, editores. Pesquisa qualitativa com texto, imagem e som: um manual prático. 9a ed. Rio de Janeiro: Vozes; 2011. p.416-42.

17. Azevedo DM, Costa RKS, Miranda FAN. Uso do ALCESTE na análise de dados qualitativos: constribuições na pesquisa de enfermagem. Rev Enferm UFPE. 2013; 7(Esp. 201):5015-22. http://dx.doi.org/ 10.5205/reuol.4700-39563-1

18. Azevedo DM, Miranda FAN. Teoria das representações sociais e ALCESTE: contribuições teóricometodológicas na pesquisa qualitativa. Sau Transf Soc. 2012; 3(4):4-10.

19. Moscovici S. Representações sociais: investigações em psicologia social. $6^{\text {a }}$ ed. Petrópolis: Vozes; 2009.

20. Soares C. Em torno do pensamento social e do conhecimento do senso comum. A aplicação da metodologia ALCESTE em contextos discursivos distintos. In: Moreira A, organizador. Perspectivas teórico-metodológicas em representações sociais. João Pessoa: UFPB; 2005. p.541-68.

21. Vincha KRR, Cardenas AP, Cervato-Mancuso AM, Vieira VL. Grupos de educação nutricional em dois contextos da América Latina: São Paulo e Bogotá. Interface. 2014; 18(50):507-20. http://dx.doi.org/ 10.1590/1807-57622014.0116

22. Gazzinelli MF, Gazzinelli ARDC, Penna CMM. Educação em saúde: conhecimentos, representações sociais e experiências da doença. Cad Saúde
Pública. 2005; 21(1):200-6. http://dx.doi.org/10. 1590/S0102-311X2005000100022

23. Amparo-Santos L. Avanços e desdobramentos do marco de referência da educação alimentar e nutricional para políticas públicas no âmbito da universidade e para os aspectos culturais da alimentação. Rev Nutr. 2013; 26(5):595-600. http://dx. doi. org/10.1590/S1415-52732013000500010

24. Recine E, Sugai A. Consenso sobre habilidades e competências do nutricionista no âmbito da saúde coletiva. Brasília: Observatório de Políticas de Segurança Alimentar e Nutrição; 2013.

25. Pinheiro ARO, Recine $E$, Alencar $B$, Fagundes $A$, Araújo SIS, Monteiro RA et al. Percepção de professores e estudante em relação ao perfil de formação de nutricionista em saúde pública. Rev Nutr. 2012; 25(5):632-43. http://dx.doi.org/10.1590/S14 15-52732012000500008

26. Mitre SM, Siqueira-Batista R, Girardi-de-Mendonça JM, Morais-Pinto NM, Meirelles CAB, Pinto-Porto $C$, et al. Metodologias ativas de ensino-aprendizagem na formação profissional em saúde: debates atuais. Ciên Saúde Coletiva. 2008; 13(Suppl. 2):2133-44. http://dx.doi.org/10.1590/S1413-812 32008000900018

27. Marin MJS, Lima EFG, Paviotti AB, Matsuyama DT, Silva LKD, Gonzalez C, et al. Aspectos das fortalezas e fragilidades no uso das metodologias ativas de aprendizagem. Rev Bras Educ Méd (2010); 34(1):13-20. http://dx.doi.org/10.1590/S0100-550 22010000100003

28. Kalinowski CE, Massoquetti RMD, Peres AM, Larocca LM, Cunha ICKO, Gonçalves LS, et al. Metodologias participativas no ensino da administração em Enfermagem. Interface. 2013; 17(47):959-67. http://dx.doi.org/10.1590/S1414-32832013005 000029

29. Limberger JB. Metodologias ativas de ensino-aprendizagem para educação farmacêutica: um relato de experiência. Interface. 2013; 17(47):969-75. http://dx.doi.org/10.1590/1807-57622013.3683

30. Lopes R, Tocantins FR. Promoção da saúde e a educação crítica. Interface. 2012; 16(40):235-48. http:// dx.doi.org/10.1590/S1414-32832012005000009

31. Ferreira VA, Magalhães R. Nutrição e promoção da saúde: perspectivas atuais. Cad Saúde Pública. 2007; 23(7):1674-81.

Received: September 9, 2015 Final version: February 2, 2016 Approved: July 15, 2016 
